\title{
KEWENANGAN MENGUJI KONSTITUSIONALITAS PERATURAN DAERAH TERHADAP UUD 1945
}

\author{
Oleh : \\ Indah Permatasari ${ }^{1}$
}

\begin{abstract}
The local government is given authority by the constitution to establish local regulations. Problems are arise when there are local regulation that not compatible with the constitution. The next question that arises is who is authorized to examine local regulations that not compatible with the constitution. In contrary with those considerations, the substantial problems are formulated into two, regulations about examine local regulations with the constitution and who is authorized to examine local regulations with the constitution. This legal research is normative legal research. This research used the statute approach and conceptual approach. Legal materials analysis techniques that are used in this research are description and interpretation techniques. There is no regulation about examine local regulations with the constitution. The way that can be done to examine local regulations with the constitution is lodge a judicial review to the Supreme Court and than lodge a constitutional review to the Constitutional Court. The other way to do is through a constitutional complaint, but this mechanism is not owned by the Constitutional Court. The establishment of examine local regulations with the constitution is important to provide legal certainty and the protection of constitutional rights to the citizens.
\end{abstract}

\section{Keywords: Constitution, Constitutional Court, Local Regulations, Supreme Court.}

\section{PENDAHULUAN}

\subsection{Latar Belakang}

Peraturan daerah merupakan produk hukum yang berada di bawah undangundang. Peraturan daerah memiliki peran sebagai sarana legislasi dalam pemerintahan daerah. ${ }^{2}$ Secara substansial, peraturan daerah mengatur mengenai urusan rumah tangga di bidang otonomi dan tugas pembantuan dan/atau penjabaran mengenai peraturan perundang-undangan. ${ }^{3}$

Mahasiswa Program Magister (S2) Ilmu Hukum Universitas Udayana, Denpasar, Bali, Alamat: Jalan Tunggul Ametung Gang X/25 Kec. Denpasar Utara Kota Denpasar, Email: indah.permatasari5175@ yahoo.com

H.M Laica Marzuki, Prinsip-Prinsip Peraturan Daerah, Jurnal Konstitusi, Volume 6 Nomor 4, Edisi 2009, Sekretariat Jendral dan Kepaniteraan Mahkamah Konstitusi, hlm.1.

I Nengah Suantra,dkk., 2015, Buku Ajar \& Klinik Manual Klinik Perancangan Produk Hukum Daerah, Udayana University Press, Denpasar, hlm.76.
Ketentuan Pasal 7 ayat (1) UU Nomor 12 Tahun 2011 menentukan bahwa peraturan daerah berada dibawah undang- undang. Konsekuensi dari ketentuan pasal diatas ialah peraturan daerah tidak boleh bertentangan dengan ketentuan perundang-undangan yang lebih tinggi.

Proses pembentukan peraturan daerah yang materi muatannya konstitusional, bukanlah hal yang mudah. Tidak menutup kemungkinan bahwa ditemukan peraturan daerah yang materi muatannya bertentangan dengan peraturan perundang-undangan yang berada di atasnya.

Berdasarkan hal tersebut maka diperlukan lembaga yang berwenang untuk menguji konstitusionalitas peraturan daerah terhadap peraturan perundang-undangan yang berada di atasnya. Lembaga yang 
diberikan kewenangan untuk menguji peraturan daerah terhadap undang-undang adalah Mahkamah Agung. Hal tersebut merupakan kewenangan yang diberikan oleh UUD 1945 khususnya ketentuan Pasal 24 A ayat (1).

Permasalahan yang kemudian muncul ialah apabila materi muatan peraturan daerah tersebut bertentangan dengan UUD 1945. Materi muatan peraturan daerah tentu saja memiliki kemungkinan melanggar hak asasi manusia atau bersifat diskriminatif. Pertanyaan yang muncul selanjutnya adalah siapakah lembaga yang berwenang untuk menguji peraturan daerah yang materi muatannya bertentangan dengan UUD 1945.

UUD 1945 tidak mengatur mengenai lembaga negara yang memiliki kewenangan untuk menguji konstitusionalitas peraturan daerah yang bertentangan dengan UUD 1945. Kekosongan norma hukum tersebut terlihar dalam Pasal 24C ayat 1 dan Pasal 24A UUD 1945. Kedua ketentuan pasal tersebut tidak mengatur mengenai lembaga negara yang berwenang melakukan pengujian terhadap peraturan daerah yang bertentangan dengan UUD 1945.

Tidak adanya pengaturan mengenai lembaga negara yang berwenang untuk menguji materi muatan peraturan daerah apabila bertentangan dengan UUD 1945 tentu saja menimbulkan suatu pertanyaan. Kekosongan hukum mengenai hal ini tentu saja dapat merugikan hak konstitusional warga negara akan berlakunya peraturan daerah tersebut.

Hak-hak yang diatur dalam UUD 1945 adalah hak konstitusional. Hak-hak yang diatur dalam UUD 1945 itu mencangkup hak-hak yang tergolong ke dalam hak warga negara (citizen right) maupun hak-hak yang tergolong ke dalam hak asasi manusia (human rights). ${ }^{4}$

Hak konstitusional yang dimiliki oleh warga negara tersebut tentu saja harus dilindungi dan dijamin oleh Negara Republik Indonesia sebagai negara hukum. Tidak menutup kemungkinan bahwa terdapat warga negara yang merasa hak konstitusionalnya dirugikan akan berlakunya suatu peraturan daerah yang bertentangan dengan konstitusi.

Kekosongan norma hukum mengenai lembaga yang berwenang untuk menguji peraturan daerah terhadap UUD 1945 tentu saja dapat menimbulkan kerugian bagi warga negara pencari keadilan. Berdasarkan hal tersebut penulis tertarik untuk meneliti "Kewenangan Menguji Konstitusionalitas Peraturan Daerah Terhadap UUD 1945."

\subsection{Rumusan Masalah}

Berdasarkan latar belakang yang telah dipaparkan, maka dikemukakan dua permasalahan pokok yaitu:

1. Bagaimana pengaturan mengenai pengujian peraturan daerah terhadap UUD 1945?

2. Siapakah lembaga negara yang berwenang melakukan pengujian peraturan daerah terhadap UUD $1945 ?$

\subsection{Tujuan Penelitian}

Tujuan dalam penelitian hukum ini adalah:

1. Tujuan Umum: untuk mengetahui dan menganalisa pengaturan mengenai

I Dewa Gede Palguna, 2013, Pengaduan Konstitusional (Constitutional Complaint), Sinar Grafika, Jakarta, hlm.39. 
pengujian peraturan daerah terhadap UUD 1945.

2. Tujuan Khusus: untuk mengetahui dan menganalisa lembaga negara yang berwenang menguji peraturan daerah yang bertentangan dengan UUD 1945.

\section{Metode Penelitian}

\subsection{Jenis penelitian}

Penelitian merupakan penelitian hukum normatif. Penelitian hukum normatif mencangkup penelitian terhadap asas-asas hukum, sistematik hukum, taraf sinkronisasi vertikal dan horizontal, perbandingan hukum dan sejarah hukum. ${ }^{5}$ Sudikno Mertokusomo menyatakan pendapatnya, menurut beliau penelitian hukum yang meneliti kaidah atau norma merupakan penelitian hukum normatif. ${ }^{6}$ Penelitian ini adalah penelitian hukum normatif yang menganalisis mengenai kaidah atau norma karena yang dibahas didalam penelitian ini ialah mengenai kekosongan norma hukum mengenai pengaturan kewenangan menguji konstitusionalitas peraturan daerah terhadap UUD 1945.

\subsection{Jenis Pendekatan}

Pendekatan perundang-undangan dan pendekatan konseptual dipergunakan dalam penelitian ini. Pendekatan undang-undang (the statute approach) dilakukan dengan mempergunakan undang-undang maupun regulasi berkenaan dengan permasalahan yang akan dianalisis. ${ }^{7}$

Soerjono Soekanto dan Sri Mamudji, 2013, Penelitian Hukum Normatif Suatu Tinjauan Singkat, PT. Raja Grafindo Persada, Jakarta, hlm.14.

6 Sudikno Merokusumo, 2014, Penemuan Hukum, Cahaya Atma Pustaka, Yogyakarta,hlm.37.

Peter Mahmud Marzuki, 2011, Penelitian Hukum Prenada Media Group, Jakarta, hlm.93.
Pendekatan perundang-undangan dipergunakan untuk mengkaji peraturan perundang-undang yang akan dipergunakan untuk membahas permasalahan yang dikaji. Pendekatan konseptual (conceptual approach) dipergunakan dalam penelitian tesis ini dikarenakan penelitian ini nantinya akan membahas mengenai konsep hukum yang memiliki keterkaitan dengan permasalahan yang dikaji khususnya konsep judicial review.

\subsection{Sumber Bahan Hukum}

Bahan hukum terdiri dari bahan hukum primer, sekunder, dan tersier. ${ }^{8}$ Peraturan perundang undangan dan putusan-putusan hakim tergolong kedalam bahan hukum primer. ${ }^{9}$ Adapun peraturan perundangundangan yang dipergunakan adalah: UUD NRI Tahun 1945, UU No. 3 Tahun 2009 Tentang Perubahan Kedua Atas UU No. 14 Tahun 1985 Tentang Mahkamah Agung, UU No. 12 Tahun 2011 Tentang Pembentukan Peraturan Perundang-undangan.

Penjelasan yang berkaitan dengan bahan hukum primer disebut sebagai bahan hukum sekunder. Bahan hukum sekunder dalam penelitian ini meliputi karya tulis hukum yang berada dalam majalah (artikel), pendapat para pakar hukum, buku hukum, dan artikel dari perkembangan informasi internet.

Bahan hukum tersier, adalah bahan yang menjelaskan hal-hal yang berkaitan dengan bahan hukum primer dan bahan hukum sekunder. Bahan hukum tersier yang digunakan berupa kamus hukum, kamus bahasa Indonesia, dan kamus ilmiah.

Ibid.

Ibid.,hlm.141. 


\subsection{Teknik Pengumpulan Hukum}

Teknik studi dokumen dipergunakan sebagai teknik pengumpulan bahan hukum. Teknik studi dokumen pada dasarnya dipergunakan atas bahan hukum yang relevan dengan penelitian.

\subsection{Teknik Pengolahan dan Analisis Bahan Hukum}

Teknik analisis bahan hukum yang dipergunakan dalam penelitian ini adalah teknik deskripsi dan teknik interpretasi. Salah satu cara penemuan hukum yang dapat memberikan penjelasan tentang isi dari undang-undang disebut sebagai Interpretasi atau penafsiran ${ }^{10}$ Penafsiran teleologis dan penafsiran oleh hakim atau pengadilan (judicial interpretation) dipergunakan untuk menganalisis permasalahan yang ada dalam penelitian ini.

\section{HASIL DAN PEMBAHASAN}

\subsection{Pengaturan Mengenai Pengujian Peraturan Daerah Terhadap UUD 1945}

Kewenangan untuk membuat atau menetapkan peraturan daerah diberikan kepada pemerintah daerah. Peraturan daerah dipergunakan untuk melaksanakan otonomi dan tugas pembantuan. UUD 1845 mengatur mengenai kewenangan yang diberikan kepada pemerintah daerah khususnya dalam ketentuan Pasal 18 ayat (6).

Kewenangan pengujian peraturan daerah terhadap UUD 1945 memang tidak diatur dalam konstitusi maupun peraturan perundang-undangan. UUD 1945 hanya

Ahmad Rifai, 2011, Penemuan Hukum Oleh Hakim Dalam Perspektif Hukum Progresif, Sinar Grafika, Jakarta.,hlm.61. mengatur kewenangan menguji peraturan daerah terhadap undang-undang yang merupakan kewenangan Mahkamah Agung. Hal tersebut merupakan kewenangan yang diberikan oleh UUD 1945 khususnya ketentuan Pasal 24A ayat (1). Adapun isi ketentuan Pasal 24 A ayat (1) adalah menentukan bahwa Mahkamah Agung memiliki kewensngsn untuk peraturan perundang-undangan di bawah undangundang yakni termasuk peraturan daerah terhadap undang-undang.

Mahkamah Agung memiliki kewenangan untuk menyatakan tidak sah suatu peraturan perundang-undangan di bawah undang-undang atas alasan bertentangan dengan peraturan perundangundangan yang berada diatasnya atau pembentukannya tidak sesuai dengan aturan yang ada. Apabila peraturan daerah tersebut bertentangan dengan peraturan perundangundangan yang berada diatasnya maka Mahkamah Agung dalam putusannya dapat menyatakan bahwa materi muatan atau peraturan daerah tersebut tidak memiliki kekuatan hukum mengikat.

Mahkamah Konstitusi, apabila dilihat dalam ketentuan Pasal $24 \mathrm{C}$ ayat (1) juga tidak memiliki kewenangan untuk menguji konstitusionalitas peraturan daerah apabila bertentangan dengan UUD 1945. UUD 1945 hanya memberikan kewenangan untuk menguji undang-undang terhadap UUD 1945 kepada Mahkamah Konstitusi.

Dari ketentuan pasal diatas dapat diketahui bahwa UUD 1945 maupun undang-undang yang lainnya tidak mengatur mengenai kewenangan pengujian peraturan daerahterhadapUUD1945.Pengkonstruksian pengaturan mengenai kewenangan pengujian peraturan daerah terhadap UUD 1945 penting 
untuk dilakukan. Hal ini dikarenakan tidak menutup kemungkinan munculnya peraturan daerah yang bertentangan dengan UUD 1945.

Setiap pemerintah daerah memiliki kewenangan untuk menetapkan peraturan daerah yang merupakan konsekuensi diterapkannya otonomi daerah. Peraturan daerah yang materi muatannya bertentangan dengan UUD tentu saja dapat menimbulkan permasalahan, salah satu contohnya ialah peraturan daerah di Tolikarang. Kasus tersebut menjadi contoh bahwa adanya peraturan daerah yang materi muatannya bertentangan dengan konstitusi khususnya Pasal 28E ayat (1) UUD 1945.

Adanya peraturan daerah yang materi muatannya bertentangan dengan konstitusi tersebut tentu saja dapat merugikan hak konstitusional warga negara. UUD 1945 dalam Pasal 1 ayat (3) secara tegas menentukan bahwa Negara Indonesia adalah negara hukum. Negara yang berdasarkan Hukum yang menjamin keadilan bagi warganya merupakan ciri negara hukum. ${ }^{11}$

Salah satu unsur Negara Hukum (Rechtsstaat) menurut J.F Sthal ialah adanya pengakuan akan hak-hak dasar manusia. Konsekuensinya ialah Negara Republik Indonesia yang merupakan negara hukum wajib untuk melindungi hak-hak konstitusional warga negaranya. Perlindungan hak konstitusional warga negara dalam hal ini dapat dilakukan dengan cara pengkonstruksian norma hukum mengenai pengaturan pengujian peraturan daerah terhadap UUD.

Hotma P.Sibuea, ,2010, Asas Negara Hukum,Peraturan Kebijakan\& Asas-Asas Umum Pemerintahan yang Baik, Erlangga, Jakarta, hlm.48.
3.2 Lembaga Negara yang Berwenang Melakukan Pengujian Terhadap Peraturan Daerah yang Bertentangan dengan UUD 1945.

Mahkamah Agung hanya berwenang menguji peraturan daerah terhadap undangundang, sedangkan Mahkamah Konstitusi berwenang menguji konstitusionalitas undang-undang dengan batu uji UUD. Hal tersebut menimbulkan suatu pertanyaan mengenai lembaga manakah yang berwenang melakukan pengujian terhadap peraturan daerah yang bertentangan dengan UUD 1945.

Permasalahan kemudian muncul apabila terdapat seorang warga negara yang merasa hak konstitusionalnya dirugikan atas berlakunya peraturan daerah yang bertentangan dengan UUD 1945. Lembaga manakah yang harus dituju oleh warga negara pencari keadilan tersebut untuk melindungi hak konstitusionalnya.

Warga negara yang merasa dirugikan hak konstitusionalnya atas berlakunya peraturan daerah memiliki hak untuk mengajukan permohonan agar peraturan daerah yang bertentangan dengan konstitusi tersebut dibatalkan. Cara yang dapat ditempuh oleh warga negara tersebut terdiri dari prosedur yang cukup panjang.

Pertama, warga negara tersebut harus mengajukan pengujian peraturan daerah terhadap undang-undang ke Mahkamah Agung terlebih dahulu. Setelah Mahkamah Agung menyatakan dalam putusannya bahwa peraturan daerah tersebut bertentangan dengan undang-undang, maka maka warga negara yang dirugikan hak atau kewenangan konstitusionalnya tersebut dapat melakukan permohonan pengujian undang-undang tersebut ke Mahkamah Konstitusi. 
Kedua, undang-undang yang menjadi payung berlakunya perda tersebut diajukan ke Mahkamah Konstitusi untuk diuji konstitusionalitasnya terhadap UUD 1945, baik dari segi materi muatannya maupun prosedur pembentukannya.

Melalui prosedur yang cukup panjang tersebut dapat diketahui bahwa pengujian peraturan daerah yang bertentangan dengan konstitusi dimungkinkan untuk dilakukan. Sehingga peraturan daerah yang materi muatannya bertentangan dengan konstitusi dapat dinyatakan tidak memiliki kekuatan hukum mengikat.

Permasalahan baru dapat muncul apabila peraturan daerah tersebut dinyatakan tidak bertentangan dengan undang-undang oleh Mahkamah Agung dalam putusannya. Padahal, tidak menutup kemungkinan bahwa peraturandaerahtersebutbertentangandengan UUD 1945. Persoalan tersebut menimbulkan permasalahan yang baru mengenai siapakah lembaga yang berwenang untuk menguji konstitusionalitas peraturan daerah tersebut. Tidak menutup kemungkinan bahwa terdapat peraturan daerah yang materi muatannya bertentangan dengan konstitusi namun tidak bertentangan dengan undang-undang.

Berkaitan dengan permasalahan tersebut I Dewa Gede Palguna menyatakan bahwa permasalahan tersebut tergolong kedalam objek pengaduan konstitusional (constitutional complaint). Pengaduan konstitusional adalah pengaduan atau gugatan yang diajukan oleh perorangan ke mahkamah konstitusi terhadap perbuatan (atau kelalaian) suatu lembaga publik yang mengakibatkan terlanggarnya hak-hak konstitusionalnya ${ }^{12}$. Mekanisme pengaduan

12 I Dewa Gede Palguna, op.cit., hlm.1. konstitusional ini memang sampai saat ini belum dimiliki oleh Mahkamah Konstitusi Indonesia.

Penambahan kewenangan untuk menguji peraturan daerah terhadap UUD 1945 merupakan hal yang logis hal ini dikarenakan Mahkamah Konstitusi merupakan lembaga negara yang bertugas mengawal pelaksanaan konstitusi sekaligus mencegah terjadinya pelanggaran terhadap konstitusi. ${ }^{13} \quad$ Mahkamah Konstitusi juga merupakan pelindung (protector) konstitusi. $^{14}$

Pada hakekatnya, Mahkamah Konstitusi berfungsi untuk mengawal konstitusi tetap berjalan secara konsisten (the guardian of constitutions). ${ }^{15}$ Penambahan kewenangan ini dapat dilakukan melalui penafsiaran hakim (judicial interpretation). Berdasarkan fungsi dan tugas Mahkamah Konstitusi tersebut tidak menutup kemungkinan bahwa Mahkamah Konstitusi diberikan kewenangan untuk menguji peraturan daerah yang bertentangan dengan UUD 1945.

\section{PENUTUP}

\subsection{Simpulan}

Pengujian konstitusionalitas peraturan daerah terhadap UUD 1945 memang tidak diatur dalam konstitusi maupun peraturan perundang-undangan. Pengujian konstitusionalitas peraturan daerah terhadap

Patrialis Akbar, 2013, Lembaga-Lembaga Negara Menurut UUDNRI Tahun 1945, Sinar Grafika, Jakarta,hlm.178.

14 Maruarar Siahaan, 2012, Hukum Acara Mahkamah Konstitusi Republik Indonesia Edisi 2, Sinar Grafika, Jakarta,hlm.7.

15 Nomensen Sinamo, 2012, Hukum Tata Negara Suatu Kajian Kritis tentang Kelembagaan Negara, Permata Aksara, Jakarta,hlm.89. 
UUD 1945 dapat dilakukan dengan cara mengajukan pengujian peraturan daerah terhadap undang-undang ke Mahkamah Agung. Setelah itu undang-undang tersebut diuji konstitusionalitasnya terhadap UUD 1945 oleh Mahkamah Konstitusi. Cara lain yang dapat dilakukanialahmelaluipengaduan konstitusional, namun kewenangan ini belum dimiliki oleh Mahkamah Konstitusi Indonesia.

\subsection{Saran}

Dari segi substansi hukum, kepada pembentuk undang-undang diharapkan untuk menyusun suatu norma hukum mengenai kewenangan pengujian peraturan daerah terhadap UUD 1945. Pengkonstruksian norma hukum tersebut diperlukan demi kepastian hukum dan perlindungan hak konstitusional terhadap warga negara.

\section{DAFTAR BACAAN}

\section{Buku}

Akbar, Patrialis, 2013,Lembaga-Lembaga Negara Menurut UUDNRI Tahun 1945, Sinar Grafika, Jakarta.

Marzuki, Peter Mahmud, 2011, Penelitian Hukum, Prenada Media Group, Jakarta.

Merokusumo, Sudikno, 2014, Penemuan

Hukum, Cahaya Atma Pustaka, Yogyakarta.

Palguna, I Dewa Gede, 2013, Pengaduan

Konstitusional

(Constitutional

Complaint), Sinar Grafika, Jakarta.

Rifai, Ahmad, 2011, Penemuan Hukum

Oleh Hakim Dalam Perspektif Hukum Progresif, Sinar Grafika, Jakarta.

Siahaan, Maruarar, 2012, Hukum Acara Mahkamah Konstitusi Republik Indonesia Edisi 2, Sinar Grafika.
Sibuea, Hotma P.,2010,Asas Negara Hukum,Peraturan Kebijakan\& AsasAsas Umum Pemerintahan yang Baik, Erlangga, Jakarta

Sinamo, Nomensen, 2012, Hukum Tata Negara Suatu Kajian Kritis tentang Kelembagaan Negara, Permata Aksara, Jakarta.

Soekanto, Soerjono dan Sri Mamudji, 2013, Penelitian Hukum Normatif Suatu Tinjauan Singkat, PT. Raja Grafindo Persada, Jakarta.

Suantra, I Nengah,dkk., 2015, Buku Ajar \& Klinik Manual Klinik Perancangan Produk Hukum Daerah, Udayana University Press, Denpasar.

\section{Jurnal}

Marzuki, H.M Laica, Prinsip-Prinsip Peraturan Daerah, Jurnal Konstitusi, Volume 6 Nomor 4, Edisi 2009, Sekretariat Jendral dan Kepaniteraan Mahkamah Konstitusi, Jakarta.

\section{Perundang-undangan}

UUD NRI Tahun 1945

UU No. 3 Tahun 2009 Tentang Perubahan Kedua Atas UU No. 14 Tahun 1985 Tentang Mahkamah Agung.

UUNo. 12 Tahun2011 Tentang Pembentukan Peraturan Perudang-undangan.

\section{Biodata Penulis:}

Indah Permatasari, $\mathrm{SH}$

Jalan Tunggul Ametung X/25 Denpasar 082341417215

indah.permatasari5175@yahoo.com 